GLOBAL JOURNAL OF AGRICULTURAL SCIENCES VOL. 12, 2013: 81-89

COPYRIGHT@ BACHUDO SCIENCE CO. LTD PRINTED IN NIGERIA ISSN 1596-2903

\title{
EFFECT OF N, P AND FYM RATES ON DM ACCUMULATION AND UPTAKE OF K, CA AND MG BY ROSELLE (HIBISCUS SABDARIFFA L.) IN THE NORTHERN GUINEA SAVANNAH ZONE OF NIGERIA
}

\author{
S. M. MAUNDE, I. J. TEKWA AND B. ABUBAKAR \\ (Received 15 August 2012; Revision Accepted 10 October 2012)
}

\begin{abstract}
An investigation was conducted during 2005, 2006 and 2007 wet seasons at the experimental farm of the institute of Agricultural Research, Samaru $\left(11^{\circ} 11^{\prime} \mathrm{N}, 07^{\circ} 38^{\prime} \mathrm{E}, 686 \mathrm{~m}\right.$ above sea level) to study the effect of $\mathrm{N}, \mathrm{P}$ and farmyard manure (FYM) rates on dry matter (DM) accumulation and uptake of cations by Roselle in the Northern Guinea Savanna agro-ecological zone of Nigeria. The experiment consisted of three levels of $\mathrm{N}(0,60$ and $120 \mathrm{~kg} \mathrm{~N}$ $\left.\mathrm{ha}^{-1}\right)$ in the form of urea, three levels of $\mathrm{P}\left(0,13.2\right.$ and $\left.26.4 \mathrm{~kg} \mathrm{P} \mathrm{ha}^{-1}\right)$ in the form of single super phosphate (SSP) and three levels of $\operatorname{FYM}\left(0,5\right.$ and $\left.10 \mathrm{tha}^{-1}\right)$. A total of twenty seven treatments were laid out in a split plot design with three replications. The factorial combinations of $\mathrm{N}$ and $\mathrm{P}$ were assigned to the main plots, while the $\mathrm{FYM}$ was allocated to the sub-plots. The result showed that application of $60 \mathrm{~kg} \mathrm{~N}$ and $5 \mathrm{t} \mathrm{FYM} \mathrm{ha-1} \mathrm{recorded} \mathrm{significant} \mathrm{increase} \mathrm{in} \mathrm{DM}$ accumulation in Roselle, while applied P had no significant effect on DM production. Combined application of $120 \mathrm{~kg}$ $\mathrm{N}$ ha ${ }^{-1}$ with 5 t FYM ha ${ }^{-1}$ was optimum for DM production in Roselle. $\mathrm{N}$ application reduced $\mathrm{K}$ and $\mathrm{Mg}$ content but increased the uptake of the nutrients. Similarly, FYM reduced K and Ca content of shoots, while the uptake of these nutrients was increased by manure application. $\mathrm{P}$ application increased $\mathrm{K}$ and $\mathrm{Mg}$, but reduced $\mathrm{Ca}$ contents of shoots. Application of $\mathrm{P}$ did not however exert significant effect $(\mathrm{P}<0.05)$ on the $\mathrm{K}$ and $\mathrm{Mg}$ uptake, but reduced Ca uptake of Roselle. Further trial of $\mathrm{N}$ application at higher rates is recommended in the study area.
\end{abstract}

KEY WORDS: DM Accumulation, FYM, Nutrients, Multiproduct, Roselle, and "Zoborodo"

\section{INTRODUCTION}

Roselle (Hibiscus sabdariffa L.) originated in the Tropical central area of West Africa (Murdock, 1995), and is a multi-product and multi-purpose annual plant belonging to the family Malvaceae cultivated in the tropical and sub-tropical regions for its leaves, edible calyces, seeds and fibre. In Nigeria and elsewhere, the leaves are used as a vegetable, while the calyces are major raw materials in local and commercial beverages for production of vitamin $\mathrm{C}$ enriched soft drinks popularly known as "zoborodo" or "zobo" and "Roselle apple" (Fasoyiro et al.,2005). Extracts from the calyces are widely used in the treatment of many diseases like: treatment of high blood pressure (Faraji and Tarkhani, 1999), treatment of pyrexia and liver disorders (Obiafuna et al., 1994), cardiac, cancer and nerve diseases (Anon, 2008), and in the build-up of body immune system against diseases (CTA, 2001). It is an important source of natural coloring and flavoring agent in food and fruit processing industries (Mc Clintock, 2004). The seeds which contain $17-20 \%$ oil are a valuable source of edible oil (Rice et al., 1993; Abu Tarboush et al., 1997), and also a good source of protein (23\%) with high tryptophan level (Rao, 1996). The seeds are fermented and boiled for local condiment (Mera et al., 2007). It is also roasted and used as a local substitute for coffee (Morton, 1987; Aliyu and Morufu, 2006). Roselle is also an important source of fibre in India, Java and Philippines. The fibre content of fresh stem is $5-6 \%$ and $18-22 \%$ of dry weight (Rehm and Espig, 1991).

Currently, apart from the diverse uses of Roselle, the increased use of the calyces and the leaves in local and commercial beverages has led to an upsurge in demand for the crop in Nigeria. However, since production is still predominantly subsistent and mostly in mixture with other crops, and in which its specific nutrient needs and spacing are not considered, yields are generally low. As a result, the increased demand cannot be met unless appropriate production practices, especially the use of optimum rates of nutrients are adopted. Effective and efficient fertilizer use, however, emanates from the understanding of the crop's nutritional needs and its responses to nutrient supply. The relationship of nutrient supply and chemical contents of the plants were uncovered by the studies of Ulrich (1952) and Smith (1962). These relationships provide a firm basis for effective fertilizer recommendation for optimum yields of Roselle crops.

S. M. Maunde, Agricultural Technology Department, Adamawa State College of Agriculture, Ganye, Nigeria

I. J. Tekwa, Agricultural Technology Department, Federal Polytechnic, P.M.B 35, Mubi. Adamawa State

B. Abubakar, Agricultural Technology Department, Mohamet Lawan College of Agriculture, Maiduguri, Nigeria 
Although there is a paucity of information on the nutritional needs of Roselle in Nigeria (Kumar et al., 1985 and Aliyu, 1998), studies by Adamson et al., (1979) and Bhangoo et al., (1986) on Kenaf indicated that $\mathrm{N}$ application reduced $\mathrm{K}$ contents of whole plants, while the application of $\mathrm{N}$ and $\mathrm{P}$ increased $\mathrm{K}$ content and Ca uptake of pepper (Aliyu, 1994). This study was, therefore, undertaken to investigate the effect of $\mathrm{N}, \mathrm{P}$ and FYM on DM accumulation and the uptake of $\mathrm{K}, \mathrm{Ca}$ and $\mathrm{Mg}$ by Roselle plant.

\section{Materials and Methods}

The study was conducted during 2005, 2006 and 2007 wet seasons at the experimental farm of the Institute of Agricultural Research, Samaru $\left(11^{\circ} 11^{\prime} \mathrm{N}, 07^{\circ}\right.$ $38^{\prime} \mathrm{E} 686 \mathrm{~m}$ above sea level) in the Northern Guinea Savanna ecological zone of Nigeria. This was to determine the effect of various combinations of 3 levels of $N\left(0,60\right.$ and $\left.120 \mathrm{KgNha}^{-1}\right), 3$ levels of $P(0,13.2$ and $\left.26.4 \mathrm{kgPha}^{-1}\right)$ and 3 levels of FYM $\left(0,5\right.$ and $\left.10 \mathrm{t} \mathrm{ha}^{-1}\right)$ on the growth and nutrient uptake of Roselle (Hibiscus sabdariffa L.). Urea $(46 \% \mathrm{~N})$ and single super phosphate $\left(18 \% \mathrm{P}_{2} \mathrm{O}_{5}\right)$ were used as sources of $\mathrm{N}$ and $\mathrm{P}$, respectively, while the FYM (FYM) used was cowdung mixed with bedding materials. Before application, samples from the FYM were taken and analyzed in order to determine its chemical contents. A split plot design was used with factorial combination of $\mathrm{N}$ and $\mathrm{P}$ rates allocated to the main plots. Treatments were replicated three times. The gross plots $\left(13.5 \mathrm{~m}^{2}\right)$ were made up of 6 ridges of $3 \mathrm{~m}(3 \times 3 \mathrm{~m})$. Composite samples of soils at depths of $0-15$ and $15-30 \mathrm{~cm}$ were taken from the experimental sites prior to crop establishment and application of fertilizer treatments and analyzed for the chemical and physical properties using standard laboratory procedures (Black, 1965).

Planting was done on ridges at $75 \mathrm{~cm}$ apart and $3 \mathrm{~m}$ long at intra-row spacing of $60 \mathrm{~cm}$. The application rates of $P$ and $F Y M$ as well as the base dose of $30 \mathrm{~kg} \mathrm{~K}$ $\mathrm{ha}^{-1}$ were side banded and incorporated 2 weeks before Roselle seeds were planted. Two-hoe-weeding at 3 and 7 WAS and ridge molding at 11 WAS were done to control weeds. Karate (Lambdacyhalothrin) at the rate of 0.8 litre ha ${ }^{-1}$ along with Benlate (benomyl) at the rate of $1 \mathrm{Kgai}^{-1} \mathrm{ha}^{-1}$ were applied three times fortnightly using knapsack sprayer starting from 3 WAS each season as a routine preventive measure against pest and disease incidences. At 10 WAS, 2 plants were sampled randomly from each plot and thoroughly cleaned and dried to constant weight for the determination of total dry matter (TDM) after which it was ground with a Wiley mill and passed through a $2 \mathrm{~mm}$ sieve. Total $\mathrm{N}$ in plant tissues was determined by Micro-Kjeldahl procedure (IITA, 1975). The percent concentration of $P$ was determined by the vanodomolybdate yellow colour of Bray and Kurtz (1945) modified by Riley (1962). The concentration of $\mathrm{K}, \mathrm{Ca}$, and $\mathrm{Mg}$ were determined by atomic absorption spectrophotometry using Perking Elmer model 290B. The data collected were subjected to statistical analysis of variance as described by Senedecor and Cochran (1967). The data generated was analysed following the generalized linear model for the ANOVA (Statistix 8.0), while the differences between treatment means were determined using DMRT (Duncan, 1955).

\section{RESULTS AND DISCUSSIONS}

The soils of the experimental sites were: clay loam in 2005, loam in 2006 and sandy loam in 2007; with moderate acidity in 2005 and 2007, while it was strongly acidic in 2006 (Table 1). During the 3 seasons, the soils had low organic carbon, $\mathrm{N}$ and medium exchangeable $\mathrm{K}$, while available $\mathrm{P}$ was low in 2005 but medium in 2006 and 2007 seasons. Detail of the physico-chemical properties of the soils of the experimental site is presented in Table I. 
Table 1: Physico-chemical properties of soils of the experimental site during 2005, 2006 and 2007 wet seasons

\begin{tabular}{|c|c|c|c|c|c|c|}
\hline & \multicolumn{2}{|c|}{$\begin{array}{l}2005 \\
\text { Soil depth (cm) }\end{array}$} & \multicolumn{2}{|c|}{$\begin{array}{l}2006 \\
\text { Soil depth (cm) }\end{array}$} & \multicolumn{2}{|c|}{$\begin{array}{l}2007 \\
\text { Soil depth }(\mathrm{cm})\end{array}$} \\
\hline & $0-15$ & $15-30$ & $0-15$ & $15-30$ & $0-15$ & $15-30$ \\
\hline \multicolumn{7}{|c|}{ Particle size distribution (\%) } \\
\hline Clay & 18 & 42 & 24 & 24 & 10 & 26 \\
\hline Silt & 52 & 22 & 34 & 34 & 32 & 34 \\
\hline Sand & 30 & 36 & 42 & 46 & 58 & 40 \\
\hline \multirow{2}{*}{\multicolumn{7}{|c|}{ Textural characteristics }} \\
\hline & & & & & & \\
\hline $\mathrm{pH}$ in water & 6.0 & 6.56 & 5.40 & 5.30 & 6.20 & 6.30 \\
\hline $\mathrm{pH}$ in $0.01 \mathrm{M} \mathrm{CaCl}_{2}$ & 5.2 & 4.90 & 4.84 & 4.84 & 5.10 & 4.80 \\
\hline Organic carbon $\left(\mathrm{gkg}^{-1}\right)$ & 12.40 & 4.00 & 9.60 & 4.00 & 6.00 & 4.28 \\
\hline Total $N\left(\mathrm{gkg}^{-1}\right)$ & 0.35 & 0.54 & 1.10 & 0.52 & 1.33 & 1.24 \\
\hline $\begin{array}{l}\text { Available } \mathrm{P}\left(\mathrm{mgkg}^{-1}\right) \\
\text { Exchangeable bases }(\end{array}$ & 7.13 & 1.78 & 6.20 & 8.40 & 17.50 & 7.00 \\
\hline $\mathrm{Ca}$ & 0.56 & 0.98 & 1.08 & 0.42 & 0.37 & 0.93 \\
\hline $\mathrm{Mg}$ & 0.45 & 1.15 & 0.63 & 0.41 & 1.17 & 2.36 \\
\hline $\mathrm{K}$ & 0.23 & 0.26 & 0.18 & 0.27 & 0.17 & 0.19 \\
\hline $\mathrm{Na}$ & 0.47 & 0.22 & 0.54 & 0.43 & $0 / 33$ & 0.37 \\
\hline $\begin{array}{l}\text { Exchangeable acidity } \\
(\mathrm{H}+\mathrm{Al})\end{array}$ & 0.20 & 0.20 & 0.20 & 0.20 & 0.18 & 0.18 \\
\hline CEC & 6.80 & 13.00 & 8.60 & 7.20 & 8.40 & 12.50 \\
\hline
\end{tabular}

DM accumulation as influenced by the N, P and FYM rates is presented in Table 2. Application of both rates of $\mathrm{N}$ resulted in similar but significantly $(\mathrm{P}<0.05)$ higher TDM production over the control in 2005 and combined data, while in 2006 and 2007, each increase in $\mathrm{N}$ rate led to a significant increase in DM accumulation. The positive influence of $\mathrm{N}$ on TDM could be due to its role in promoting rapid vegetative growth and its direct effect on cell division, expansion and synthesis of enzymes and chlorophyll (Brady and Weil, 2004). The application of both rates of FYM resulted in comparable but significantly $(\mathrm{P}<0.05)$ high $\mathrm{DM}$ accumulation over plots with no manure treatments (Table 2). The positive influence of FYM on TDM could be attributed to the ability of manure to improve soil physical condition and supply of essential nutrients required for vegetative growth (Eghball 2002; Anon, 2007 and Bationo et al., 2007). 
Table 2: Total DM of Roselle as influenced by N, P and FYM rates at various seasons

\begin{tabular}{|c|c|c|c|c|}
\hline \multirow[b]{2}{*}{ Treatments } & \multicolumn{4}{|c|}{ Seasons } \\
\hline & 2005 & 2006 & 2007 & Mean \\
\hline \multicolumn{5}{|l|}{$\mathbf{N}\left(\mathrm{KgNha}^{-1}\right)$} \\
\hline 0 & 56.7 & $82.5 \mathrm{c}$ & $50.9 c$ & $61.3 \mathrm{~b}$ \\
\hline 60 & 67.0 & $106.7 \mathrm{~b}$ & $75.8 b$ & $80.6 \mathrm{a}$ \\
\hline 120 & 75.6 & $119.4 a$ & $86.2 a$ & $90.3 a$ \\
\hline SE \pm & 5.34 & 4.65 & 2.97 & 4.32 \\
\hline \multicolumn{5}{|c|}{$P\left(K_{g} P h^{-1}\right)$} \\
\hline 0 & 76.7 & 110.4 & 73.1 & 86.7 \\
\hline 13.2 & 75.5 & 121.0 & 72.3 & 89.6 \\
\hline 26.4 & 74.1 & 119.4 & 67.6 & 87.0 \\
\hline SE \pm & 5.34 & 4.65 & 2.97 & 4.32 \\
\hline \multicolumn{5}{|l|}{ FYM $\left(t h^{-1}\right)$} \\
\hline 0 & $56.2 b$ & $98.0 \mathrm{~b}$ & $63.3 b$ & 70.3 \\
\hline 5 & $82.1 \mathrm{a}$ & $129.3 a$ & $73.2 \mathrm{a}$ & $94.9 a$ \\
\hline 10 & $88.0 \mathrm{a}$ & $123.5 a$ & $76.4 a$ & $96.0 \mathrm{a}$ \\
\hline SE \pm & 4.48 & 3.61 & 2.14 & 3.41 \\
\hline \multicolumn{5}{|l|}{ Interaction } \\
\hline $\mathrm{NxP}$ & NS & NS & NS & NS \\
\hline $\mathrm{NxM}$ & NS & NS & $* *$ & NS \\
\hline PxM & NS & NS & NS & NS \\
\hline$N x P x M$ & NS & NS & NS & NS \\
\hline
\end{tabular}

Means followed by unlike letter(s) within a treatment group column differ significantly using DMRT ( $P=0.05)$. NS=Not significant, ${ }^{* *}=$ Significant at $\mathrm{P}=0.01$

$\mathrm{P}$ application had no significant $(\mathrm{P}<0.05)$ effect on $\mathrm{DM}$ production in all the years of study and even their combined effect (Table 2), probably because unlike $\mathrm{N}$, it doesn't promote aerial vegetative growth of most crops. It could also be linked to the presence of appreciable amount of $\mathrm{P}$ in the experimental soils especially in 2007 season (Table I).

The influence of $\mathrm{N}$ and FYM interaction on DM accumulation is shown in Table 3. The application of $120 \mathrm{Kg} \mathrm{N}$ $\mathrm{ha}^{-1}$ with either rates of FYM maximized DM production in Roselle. The significant and positive effect of an interaction between $\mathrm{N}$ and FYM on DM production further affirmed the critical roles of $\mathrm{N}$ and FYM in promoting growth and DM accumulation, and the complementarity of using both on crops (Quinones, et al., 1997; Bationo, 2008).

Table 3: TDM of roselle as influenced by significant interaction between N and FYM in 2007

\begin{tabular}{llll}
\hline & \multicolumn{2}{l}{ FYM $\left(\mathrm{t} \mathrm{ha}^{-1}\right)$} & \\
\cline { 2 - 4 } & 0 & 5 & 10 \\
\hline $\mathrm{N}\left(\mathrm{KgNha}^{-1}\right)$ & & $51.0 \mathrm{c}$ & $53.5 \mathrm{c}$ \\
0 & $48.1 \mathrm{c}$ & $76.5 \mathrm{~b}$ & $77.5 \mathrm{~b}$ \\
60 & $73.5 \mathrm{~b}$ & $92.2 \mathrm{a}$ & $98.1 \mathrm{a}$ \\
120 & $68.4 \mathrm{~b}$ & 4.24 & \\
$\mathrm{SE} \pm$ & & &
\end{tabular}

Means followed by different letter(s) within a set of interaction differ significantly using DMRT $(P=0.05)$ 
Applied $\mathrm{N}$ reduced $\mathrm{K}$ and $\mathrm{Mg}$, and only increased $\mathrm{Ca}$ concentration in 2007, while the uptake of all the cations by Roselle was increased following $\mathrm{N}$ application (Tables 5, 6 and 7). The reduction of $\mathrm{K}$ and $\mathrm{Mg}$ probably resulted from the increased demand for them with $\mathrm{N}$ application which enhanced the growth of the crop. Similarly, because of increased demand for these nutrients more growth stimulated nutrient uptake.
According to Brady and Weil (2004) provision of sufficient quantities of $\mathrm{N}$ encouraged rapid vegetative growth and regulates the uptake of $\mathrm{K}$ and other nutrients from the soil. $\mathrm{P}$ application increased $\mathrm{K}$ and $\mathrm{Mg}$ but reduced $\mathrm{Ca}$ concentration in shoots (Tables 4, 5 and 6). The increase in $\mathrm{K}$ and $\mathrm{Mg}$ contents by provision of sufficient quantities of $\mathrm{N}$ encouraged rapid vegetative growth and regulated the uptake of $\mathrm{K}$ and

Table 4: Potassium content (\%) and uptake $\left(\mathrm{g} \mathrm{plant}^{-1}\right)$ as influenced by $\mathrm{N}, \mathrm{P}$ and FYM rates at Samaru during 2005 , 2006 and 2007 wet seasons.

\begin{tabular}{|c|c|c|c|c|c|c|c|c|}
\hline \multirow{3}{*}{$\begin{array}{l}\text { Treatments } \\
\mathrm{N}\left(\mathrm{KgNha}^{-1}\right)\end{array}$} & \multicolumn{4}{|c|}{ Potassium (\%) } & \multicolumn{4}{|c|}{ Potassium (g plant-1 ) } \\
\hline & 2005 & 2006 & 2007 & mean & 2005 & 2006 & 2007 & mean \\
\hline & & & & & & & & \\
\hline 0 & 0.64 & $1.14 a$ & $0.89 a$ & $0.89 a$ & 0.38 & $0.62 b$ & $0.42 b$ & $0.61 \mathrm{c}$ \\
\hline 60 & 0.67 & 1.02 & $0.85 b$ & $0.85 b$ & $0.47 a b$ & $1.25 b$ & $0.63 a$ & $0.78 \mathrm{~b}$ \\
\hline 120 & 0.65 & $1.14 a$ & $0.84 b$ & 0.88 & $0.58 a$ & $1.62 \mathrm{a}$ & $0.70 a$ & $0.97 a$ \\
\hline SE \pm & 0.027 & 0.041 & 0.028 & 0.012 & 0.040 & 0.081 & 0.040 & 0.033 \\
\hline \multicolumn{9}{|l|}{$\mathrm{P}\left(\mathrm{KgPha}^{-1}\right)$} \\
\hline 0 & 0.65 & 1.07 & $0.85 b$ & $0.86 \mathrm{~b}$ & 0.46 & 1.19 & 0.57 & 0.74 \\
\hline 13.2 & 0.63 & 1.08 & $0.84 b$ & $0.85 b$ & 0.47 & 1.35 & 0.59 & 0.80 \\
\hline 26.4 & 0.67 & 1.15 & $0.89 a$ & $0.90 \mathrm{a}$ & 0.51 & 1.34 & 0.9 & 0.81 \\
\hline SE \pm & 0.027 & 0.041 & 0.028 & 0.012 & 0.040 & 0.081 & 0.040 & 0.033 \\
\hline \multicolumn{9}{|l|}{ FYM $\left(\mathrm{t} \mathrm{ha}^{-1}\right)$} \\
\hline 0 & $0.66 \mathrm{a}$ & $1.18 a$ & 0.87 & $0.91 a$ & $0.37 b$ & 1.19 & $0.52 b$ & $0.69 \mathrm{~b}$ \\
\hline 5 & $0.63 b$ & $1.06 \mathrm{~b}$ & 0.86 & $0.85 b$ & $0.45 b$ & 1.33 & $0.62 a$ & $0.80 a$ \\
\hline 10 & $0.66 \mathrm{a}$ & $1.07 b$ & 0.85 & $0.86 \mathrm{~b}$ & $0.61 a$ & 1.37 & $0.62 a$ & $0.87 a$ \\
\hline SE \pm & 0.027 & 0.039 & 0.028 & 0.011 & 0.023 & 0.047 & 0.023 & 0.019 \\
\hline \multicolumn{9}{|l|}{ Interaction } \\
\hline $\mathrm{NxP}$ & NS & NS & NS & NS & NS & NS & NS & NS \\
\hline NxM & NS & NS & NS & NS & NS & NS & NS & NS \\
\hline PxM & NS & NS & NS & NS & NS & NS & NS & NS \\
\hline NxPxM & NS & NS & NS & NS & NS & NS & NS & NS \\
\hline
\end{tabular}

Means followed by unlike letter(s) within a treatment group and column differ significantly using DMRT ( $P=0.05)$. NS= Not significant 
Table 5: Shoot calcium content (\%) and its uptake as influenced by N, P and FYM rates in 2005, 2006 and 2007 wet seasons

\begin{tabular}{|c|c|c|c|c|c|c|c|c|}
\hline \multirow{3}{*}{$\begin{array}{l}\text { Treatments } \\
\mathrm{N}\left(\mathrm{KgNha}^{-1}\right)\end{array}$} & \multicolumn{4}{|c|}{ calcium (\%) } & \multicolumn{4}{|c|}{ calcium (g plant $^{-1}$ ) } \\
\hline & 2005 & 2006 & 2007 & mean & 2005 & 2006 & 2007 & mean \\
\hline & & & & & & & & \\
\hline 0 & 1.42 & 1.46 & $1.37 \mathrm{~b}$ & 1.42 & $0.81 b$ & $1.21 \mathrm{c}$ & $0.69 c$ & $0.87 c$ \\
\hline 60 & 1.44 & 1.45 & $1.40 \mathrm{a}$ & 1.43 & $0.97 a$ & $1.55 b$ & $1.06 \mathrm{~b}$ & $1.15 b$ \\
\hline 120 & 1.42 & 1.42 & $1.41 \mathrm{a}$ & 1.42 & $0.81 b$ & $1.69 a$ & $1.22 \mathrm{a}$ & $1.28 \mathrm{a}$ \\
\hline SE \pm & 0.012 & 0.023 & 0.006 & 0.015 & 0.007 & 0.027 & 0.005 & 0.013 \\
\hline \multicolumn{9}{|l|}{$\mathrm{P}\left(\mathrm{KgP} \mathrm{ha}^{-1}\right)$} \\
\hline 0 & $1.45 a$ & $1.48 a$ & $1.43 a$ & $1.46 \mathrm{a}$ & $1.11 \mathrm{a}$ & $1.63 b$ & $1.04 a$ & $1.27 a$ \\
\hline 13.2 & $1.39 b$ & $1.43 a b$ & $1.41 \mathrm{~b}$ & $1.42 \mathrm{a}$ & $1.05 b$ & $1.73 a$ & $1.02 \mathrm{~b}$ & $1.27 \mathrm{a}$ \\
\hline 26.4 & $1.40 \mathrm{~b}$ & $1.42 b$ & $1.34 \mathrm{c}$ & $1.38 b$ & $1.04 b$ & $1.69 a$ & $0.91 \mathrm{c}$ & $1.20 \mathrm{~b}$ \\
\hline SE \pm & 0.012 & 0.023 & 0.006 & 0.015 & 0.007 & 0.027 & 0.005 & 0.013 \\
\hline \multicolumn{9}{|l|}{ FYM $\left(\mathrm{t} \mathrm{ha}^{-1}\right)$} \\
\hline 0 & $1.44 b$ & $1.41 b$ & $1.45 a$ & $1.43 a$ & $0.81 b$ & $1.38 b$ & $0.91 b$ & $1.01 b$ \\
\hline 5 & $1.48 b$ & $1.41 b$ & $1.37 \mathrm{~b}$ & $1.39 b$ & $1.22 \mathrm{a}$ & $1.82 \mathrm{a}$ & $1.02 \mathrm{a}$ & $1.32 \mathrm{a}$ \\
\hline 10 & $1.50 \mathrm{a}$ & $1.51 b$ & $1.36 \mathrm{~b}$ & $1.44 a$ & $1.32 \mathrm{a}$ & $1.86 \mathrm{a}$ & $1.04 a$ & $1.38 \mathrm{a}$ \\
\hline SE \pm & 0.006 & 0.008 & 0.002 & 0.005 & 0.004 & 0.011 & 0.002 & 0.004 \\
\hline \multicolumn{9}{|l|}{ Interaction } \\
\hline $\mathrm{NxP}$ & NS & NS & NS & NS & NS & NS & NS & NS \\
\hline NxM & NS & NS & NS & NS & NS & NS & NS & NS \\
\hline PxM & NS & NS & NS & NS & NS & NS & NS & NS \\
\hline NxPxM & NS & NS & NS & NS & NS & NS & NS & NS \\
\hline
\end{tabular}

Means followed by unlike letter(s) within a treatment group and column differ significantly using DMRT $(\mathrm{P}=0.05)$. NS= Not significant 
Table 6: Shoot Mg content (\%) and uptake $\left(\mathrm{g} \mathrm{plant}^{-1}\right)$ as influenced by N, P and FYM rates in 2005, 2006 and 2007 wet seasons

\begin{tabular}{|c|c|c|c|c|c|c|c|c|}
\hline \multirow{3}{*}{$\begin{array}{l}\text { Treatments } \\
\mathrm{N}\left(\mathrm{KgNha}^{-1}\right)\end{array}$} & \multicolumn{4}{|c|}{ Magnesium (\%) } & \multicolumn{4}{|c|}{ Magnesium (g plant ${ }^{-1}$ ) } \\
\hline & 2005 & 2006 & 2007 & mean & 2005 & 2006 & 2007 & Mean \\
\hline & & & & & & & & \\
\hline 0 & 0.82 & 0.92 & 0.85 & $0.87 a$ & $0.47 c$ & $0.76 c$ & $0.43 c$ & $0.53 c$ \\
\hline 60 & 0.79 & 0.92 & 0.80 & $0.84 b$ & $0.53 b$ & $0.98 b$ & $0.61 b$ & $0.68 b$ \\
\hline 120 & 0.84 & 0.97 & 0.85 & $0.89 a$ & $0.64 a$ & $1.16 \mathrm{a}$ & $0.73 a$ & $0.80 a$ \\
\hline $\mathrm{SE} \pm$ & 0.026 & 0.031 & 0.026 & 0.010 & 0.019 & 0.036 & 0.022 & 0.008 \\
\hline \multicolumn{9}{|l|}{$\mathrm{P}(\mathrm{Kg} \mathrm{P} \mathrm{ha-1})$} \\
\hline 0 & 0.81 & 0.93 & 0.83 & $0.86 \mathrm{~b}$ & 0.62 & 1.03 & 0.61 & 0.75 \\
\hline 13.2 & 0.79 & 0.92 & 0.81 & $0.84 b$ & 0.60 & 1.11 & 0.59 & 0.75 \\
\hline 26.4 & 0.84 & 0.96 & 0.86 & $0.89 a$ & 0.62 & 1.15 & 0.58 & 0.77 \\
\hline $\mathrm{SE} \pm$ & 0.026 & 0.031 & 0.026 & 0.010 & 0.019 & 0.036 & 0.022 & 0.008 \\
\hline \multicolumn{9}{|l|}{ FYM $\left(\mathrm{t} \mathrm{ha}^{-1}\right)$} \\
\hline 0 & 0.81 & 0.95 & 0.82 & 0.86 & $0.46 c$ & $0.93 c$ & $0.52 b$ & $0.61 b$ \\
\hline 5 & 0.82 & 0.93 & 0.85 & 0.86 & $0.67 b$ & $1.20 \mathrm{a}$ & $0.62 a$ & $0.82 \mathrm{a}$ \\
\hline 10 & 0.82 & 0.93 & 0.84 & 0.86 & $0.72 \mathrm{a}$ & $1.15 b$ & $0.64 a$ & $0.83 a$ \\
\hline SE \pm & 0.009 & 0.010 & 0.009 & 0.003 & 0.007 & 0.013 & 0.007 & 0.003 \\
\hline \multicolumn{9}{|l|}{ Interaction } \\
\hline $\mathrm{NxP}$ & NS & NS & NS & NS & NS & NS & NS & NS \\
\hline NxM & NS & NS & NS & NS & NS & NS & NS & NS \\
\hline PxM & NS & NS & NS & NS & NS & NS & NS & NS \\
\hline NxPxM & NS & NS & NS & NS & NS & NS & NS & NS \\
\hline
\end{tabular}

Means followed by unlike letter(s) within a treatment group and column differ significantly using DMRT ( $P=0.05)$. NS= Not significant

other nutrients from the soil. $\mathrm{P}$ application increased $\mathrm{K}$ and $\mathrm{Mg}$ but reduced $\mathrm{Ca}$ concentration in shoots (Tables 4,5 and 6). The increase in $\mathrm{K}$ and $\mathrm{Mg}$ contents of shoots could be due to increased development of root system by $P$, which encouraged the utilization of more nutrients and moisture from the soil (Brady and Weil, 2004).

The decrease in $\mathrm{Ca}$ content as $\mathrm{Mg}$ content increased in shoots probably corroborates the mutual antagonisms reported between $\mathrm{Ca}$ and $\mathrm{Mg}$ in plant tissues by Jones (2003) in plant tissues. The uptake of K and $\mathrm{Mg}$ by Roselle were, however, not influenced by $\mathrm{P}$ application. The effect of applied $P$ on potassium and magnesium indicated that there were adequate amounts of these nutrients in the plants while the increased $\mathrm{Ca}$ uptake may be ascribed to increased demand for it especially for subsequent reproductive phases of the crop. The effect of FYM treatments on the contents and uptake of $\mathrm{K}, \mathrm{Ca}$ and $\mathrm{Mg}$ are shown in Tables 4, 5 and 6. The decreases in $\mathrm{K}$ and $\mathrm{Ca}$ contents of Roselle shoots could be attributed to increased respiratory process and dilution effect resulting from increased growth activities following the application of FYM.
On the other hand, the uptake of $\mathrm{K}, \mathrm{Ca}$ and $\mathrm{Mg}$ were enhanced by manure application (Tables 4, 5 and 6 ). This result conforms to similar findings, that humic acid released from manure decomposition increased respiratory process, hormonal growth responses, chlorophyll content, uptake of nutrients and growth activities (Tekwa et al, 2010). It could also be attributed to the favorable soil physical conditions and increased availability of nutrients through the process of manure mineralization (Egball, 2002 and Bationo, 2007).

\section{CONCLUSION}

Based on the result, application of $60 \mathrm{~kg} \mathrm{~N}^{-1}$ and 5 t FYM ha ${ }^{-1}$ increased DM production in Roselle, while the effect of $P$ applications was not significant, statistically $(P<0.05)$. However, application of $60 \mathrm{~kg} \mathrm{~N}$ reduced both $\mathrm{K}$ and $\mathrm{Mg}$ contents, but had no influence on Ca content in the Roselle shoots. Instead, the uptake of $\mathrm{K}, \mathrm{Ca}$ and $\mathrm{Mg}$ increased linearly with $\mathrm{N}$ application rates. Likewise, the application of $26.4 \mathrm{~kg} \mathrm{P} \mathrm{ha}^{-1}$ increased $\mathrm{K}$ and $\mathrm{Mg}$, but reduced both the content and uptake of $\mathrm{Ca}$ in Roselle, It however, did not exert significant $(P<0.05)$ effect on $\mathrm{Mg}$ uptake. It was also observed that both $\mathrm{K}$ and $\mathrm{Ca}$ contents were reduced by 
the application of $5 \mathrm{t} \mathrm{FYM} \mathrm{ha-1}$. This FYM rate did not affect $\mathrm{Mg}$ content in the Roselle, but significantly $(P<0.05)$ increased the uptake of all the nutrients in the plant during the research.

\section{RECOMMENDATIONS}

It is recommended that $60 \mathrm{~kg} \mathrm{~N}^{-1}$ and $5 \mathrm{t}$ FYM ha ${ }^{-1}$ are adequate for DM production in Roselle plants. However, a further trial at higher rates of $\mathrm{N}$ application is recommended for Roselle production in the study area.

\section{REFERENCES}

Abu- Tarboush, H. M., Ahmed, S. A. and Al-Kahtani, H. A., 1997. Some nutritional and functional properties of Karkade (Hibiscus sabdariffa L.) seedproducts. Cereal Chemistry, 74: 352-355.

Adamson, W. C and Obryan, J. E., 1981. Inheritance of photosensitive in roselle (Hibiscus sabdariffa L.) and its mode of inheritance with special reference to the variation intermedius. Genetica, 43: 366-374.

Aliyu, L., 1998. Roselle (Hibiscus sabdariffa L.). Production as affected by pruning and sowing date. Journal of Agric. Tech., 6: 16-20.

Aliyu, M. and Morufu, A. L., 2006. Proximate analysis of some leafy vegetables ( Roselle, Jute and Bitter leaf ). International Journal of Food and Agricultural Research, 3: 194- 198.

Anonymous, 2007. Managing soil fertility for vegetable production. www.agnet.org.

Anonymous, (2008) "drugs. com (http://www.drugs.com/npp/roselle.htmL.)"

Bationo, A., Waswa, B., Kihara, J. and Kimetu, J., (eds). 2007. Advances in Integrated Soil Fertility Management in Sub-Saharan Africa: Challenges and Opportunities. Springer Publishers, 1077pp.

Bhangoo, M. S., Tarhrani., H. S. and Henderson, J., 1986. Effect of planting date, nitrogen levels, row spacing and plant population on kenaf performance in San Joaquim Valley. Agronomy Journal, 78(4): 600- 604.

Brady, N. C. and Weil, R. R., 2004. Elements of the Nature and Properties of Soil. $2^{\text {nd }}$ edition. Pearson and Prentice Hall, New Jersey. 606pp.

Bray, R. H. and Kurtz, L. T., 1945. Determination of total organic and available forms of phosphorus in soil. Soil Science, 59: 39-45.

CTA (2001). The Fruits We Eat. Technical Centre for Agricultural and Rural Cooperation. Washington, The Netherlands. 9-20.
Douglas, B. B. and Philips, T. D., 2008. Managing Phosphorus for Crop Production. Department of crop and soil sciences-cooperative extension. Penn. State University.http//www.cas.psu.edu.

Duncan, D. B., 1955. Multiple range and multiple F-test, Biometrics, 11: 1-42.

Eghball, B., 2002. Soil properties as influenced by phosphorus and nitrogen-based manure and compost applications. Agronomy Journal, 94: 128- 135.

Faraji, M. H. and Tarkhani,A. H., 1999. The effect of sour tea (hibiscus sabdariffa L.) on essential hypertension. Journal of Ethnopharmacology, 7: 231-236.

Fasoyiro, S. B., Babalola, S. O. and Owosibo, T., 2005. Chemical composition and sensory quality of fruit flavoured roselle (Hibiscus sabdariffa L.) drinks. World Journal of Agricultural Science, 1(2): 161-164.

IITA., 1975. Selected Methods for Soil and Plant Analysis. International Institute for Tropical Agriculture, Ibadan, 44pp

Jones, J. B., 2003. Agronomy Handbook. Management of crops, soils and their fertility. CRS PRESS. www.crcpress.com.

Kumar, V.,Idem, N. U. A. and Echekwu, C. A., 1985. Yield components of five roselle (Hibiscus sabdariffa L,) varieties in Northern Nigeria. East African Journal, 51(2): 108- 112.

McClintock, N., 2004. Roselle in Senegal and Mali. Leisa Magazine, 20.1, March, 2004, 4pp.

Mera, U. M., Singh, B. R., Magaji, M. D., Singh, A., Doro, A. K. and Singh, R. B., 2007. Response of Roselle (Hibiscus sabdariffa L.) to farmyard manure application in the Sudan Savanna zone of Nigeria. Proced. Of the third National conf. on organic Agric. Usman Danfodio University,Sokoto, Nigeria. $11-15^{\text {th }}$, November, 2007.

Morton, J., 1987. Roselle (Hibiscus sabdariffa L.). P 281-287. In. Fruits of Warm Climates. Julia, F. J. Morton eds. Miami, Florida, U.S.A.

Murduck, G. P., 1995. Africa, its peoples and their culture History. New York, Toronto, London, McGraw Hill Book Company, inc.

Murphy, J. and Riley, J. A., 1962. A modified single solution method for determination of phosphorus in natural waters. Annals of Chemistry Acta, 27: 31-36. 
Obiafuna, P. C., Owolabi, O. A., Adegunloye, B. J.,

Obiafuna, L. P. and Sofola, O. A., 1994. The petal extract of Hibiscus sabdariffa L. produces relaxation of isolated aorta. Journal of Pharmacognosy, 32: 69-74.

Quinones, M. A., Borlaug, N. E. and Dowswell, C. R., 1997. A fertilizer based green revolution for Africa. IN. Buresh,

R. J., Sanchez, P. A. and Calhaun, F., geds. Replenishing soil fertility in Africa. Soil Science Soc. of Amer. Special Publication, 51:SSSA, Madison, Wisconsin, USA, pp 81-95.

Rehm, S. and Espig, G. (1991). The Cultivated Plants of the Tropics and Sub-Tropics. CTA. D-6992, Germany. 552pp.

Rice, R. P., Rice, R. W. and Tindall, H. D., 1993. Fruits and Vegetable Production in Warm Climates, $2^{\text {nd }}$ eds. The Macmillan Press, London, Pp 198199.

Senedecor, C. W. and Cochran, W, D. J., 1967. Statistical Methods. Iowa State University, Press, USA. 507pp.

Smith, P. F., 1962. Mineral Analysis of plant tissues, Ann. Rev. of Plant Physiology, 13: 81-106.

Tekwa, I. J., H.U. Olawoye and H. Yakubu., 2010. Comparative effects of separate incorporation of cowdung and rice-husk materials on nutrient status of some Lithosols in Mubi, N.E Nigeria. International Journal of Agriculture and Biology. Vol. 12:857-860. Faisalabad-Pakistan

Ulrich, A., 1952. Physiological bases for assessing the nutritional requirements of plants. Annals of Plant Physiology, 3: 207-228. 